\title{
THE
}

\section{Association of Baseline Viral Serology and Sirolimus Regimens With Kidney Transplant Outcomes}

\author{
Alfonso H. Santos \\ J. Casey \\ Xuerong Wen \\ University of Rhode Island, xuerongwen@uri.edu \\ Karl L. Womer
}

Follow this and additional works at: https://digitalcommons.uri.edu/php_facpubs

The University of Rhode Island Faculty have made this article openly available.
Please let us know how Open Access to this research benefits you.

This is a pre-publication author manuscript of the final, published article.

Terms of Use

This article is made available under the terms and conditions applicable towards Open Access Policy Articles, as set forth in our Terms of Use.

\section{Citation/Publisher Attribution}

Santos, Alfonso H. Jr MD; Casey, Michael J. MD, MS; Xuerong, Wen PhD; Womer, Karl L. MD Association of Baseline Viral Serology and Sirolimus Regimens With Kidney Transplant Outcomes, Transplantation: February 2017 - Volume 101 - Issue 2 - p 377-386 doi: 10.1097/TP.0000000000001520

Available at: http://dx.doi.org/10.1097/TP.0000000000001520 


\title{
Association of Baseline Viral Serology and Sirolimus Regimens with Kidney Transplant Outcomes:
}

\section{A Fourteen Year Registry-Based Cohort Study in the US}

\author{
Alfonso H. Santos Jr, MD, Michael J. Casey, MD, MS, \\ Xuerong Wen, PhD, and Karl L Womer, MD
}

Division of Nephrology, Hypertension and Renal Transplantation, Department of Medicine, College of Medicine, University of Florida, Gainesville, FL, USA

\section{Corresponding Author Contact Information:}

Alfonso Santos, Jr., MD

University of Florida

College of Medicine

Division of Nephrology, Hypertension, and Renal Transplantation

1600 SW Archer Road

Medical Science Bldg., NG-4

Gainesville, Florida, 32610

Office: $352-273-8821$

Fax: $352-265-8244$

E-mail: Alfonso.Santos@medicine.ufl.edu 


\section{Authors' Disclosures}

Alfonso H. Santos, Jr, has been a principal investigator of a clinical trial funded by Forest Laboratories, LLC

The other authors of this manuscript have no conflict of interest to disclose as described by Transplantation.

FUNDING SOURCE: This work was supported by the Gatorade Trust through funds distributed by the University of Florida, Department of Medicine

\section{Authors' Contributions:}

Study concept and design: Santos, Wen

Acquisition of data: Wen

Analysis and interpretation of data: Santos, Wen, Casey, Womer

Drafting of the manuscript: Santos

Critical revision of the manuscript: Santos, Wen, Casey, Womer

Statistical analysis: Wen 


\begin{abstract}
Background:

The risks for transplant outcomes associated with baseline viral serostatus in kidney transplant recipients (KTR) on sirolimus have not been widely studied.

Methods:
\end{abstract}

We performed a cohort-study of 61590 adult KTR in 2000-2013. We used Cox regression models to determine the adjusted hazard ratio (aHR) of patient death, death-censored graft loss and posttransplant malignancy associated with the baseline serostatus [+ or -: Hepatitis B core (HBc), Hepatitis C (HCV), Epstein Barr (EBV) or Cytomegalovirus (CMV)] in KTR on sirolimus+mycophenolate (SRL+MPA) or sirolimus+tacrolimus (SRL+Tac), relative to the control-regimen: tacrolimus+mycophenolate (Tac+MPA)

Results:

Compared with Tac+MPA, SRL+MPA and SRL+Tac were associated with higher risks of 5-year mortality $[(\mathrm{aHR}=1.4195 \% \mathrm{CI}=1.23-1.60)$ and $(\mathrm{aHR}=1.59,95 \% \mathrm{CI}=1.38-1.83)$, respectively $)$ and death-censored graft loss, $[(\mathrm{aHR}=1.41,95 \% \mathrm{CI}=1.24-1.60)$ and $(\mathrm{aHR}=1.38,95 \% \mathrm{CI}=1.21-$ 1.57), respectively]. In KTR with negative pretransplant EBV, CMV, HBc or HCV serostatus, SRL+MPA not SRL+Tac was associated with a lower risk of posttransplant malignancy compared with control $[(\mathrm{aHR}=0.27,95 \% \mathrm{CI}=0.10-0.72), \quad(\mathrm{aHR}=0.61,95 \% \mathrm{CI}=0.43-0.88)$, $(\mathrm{aHR}=0.79,95 \% \mathrm{CI}=0.64-0.97)$ and $(\mathrm{aHR}=0.80,95 \% \mathrm{CI}=0.65-0.98)$; respectively for SRL+MPA] and $[(\mathrm{aHR}=0.98,95 \% \mathrm{CI}=0.52-1.80),(\mathrm{aHR}=0.69,95 \% \mathrm{CI}=0.46-1.06),(\mathrm{aHR}=0.83,95 \% \mathrm{CI}=0.66-$ 1.06) and $(\mathrm{aHR}=0.85,95 \% \mathrm{CI}=0.67-1.07)$; respectively for $\mathrm{SRL}+\mathrm{Tac}$. In KTR with positive serostatus to any of the above viruses, SRL+MPA or SRL+Tac was not associated with a different malignancy risk compared with control. 


\section{Conclusion:}

Compared with Tac+MPA, SRL-regimens were associated with higher risks for patient death and graft loss; although, SRL+MPA was associated with a lower risk for posttransplant malignancy in kidney allograft recipients with negative pre-transplant $\mathrm{HBc}, \mathrm{HCV}, \mathrm{EBV}$ or CMV serology. 


\section{Introduction}

A primary or reactivation viral infection after kidney transplantation can have serious impact on patient and graft outcomes. Direct effects of viral infections can range from nonspecific systemic syndromes to tissue invasive diseases involving the allograft or other organs [1,2]. By further impairment of host immune defenses, some viruses can promote other opportunistic infections $[2,3]$. Indirect effects of viral infections include alteration of surface human leukocyte antigen expression and release of growth factors and chemokines that can lead to acute and chronic rejection $[2,4,5,6]$. Viral infections can directly promote posttransplant malignancies by causing dysregulation in cellular proliferation-antiproliferation pathways $[\mathbf{2}, \mathbf{6}]$.

Potent immunosuppression which has reduced graft rejection rates and improved graft survival rates after kidney transplantation can promote viral infections which by various mechanisms can contribute to allograft failure and recipient morbidity and mortality [1]. The impairment of immune control of viral oncogenes by immunosuppression can also lead to posttransplant malignancies [2, 6, 7-18]. Interestingly, some animal and human studies have shown that a class of immunosuppressant drugs, the mammalian target of rapamycin (mTor) inhibitors, also possess anti-viral and anti-neoplastic properties $[\mathbf{1 8 , 3 5 , 2 0 , 2 1 , 2 2 ] .}$

Laboratory studies have shown an important role for mTOR signaling in the pathogenesis of fungal, parasitic and viral infections [23, 24] and in oncogenesis [ 25-28]. Accumulating evidence from clinical studies suggest that in transplant recipients, mTOR-inhibitors participate in the inhibition of replication and clearance of Polyoma BK virus [29], reduce the incidence of Cytomegalovirus (CMV) infections and its complications [30,31] and suppress Hepatitis C virus 
(HCV) recurrence [31]. Similarly, clinical studies have shown the anti-cancer properties of mTOR-inhibitors. Kahan et al. reported that compared with other immunosuppressants, mTORinhibitors were associated with lower incidence rates for all malignancies, post-transplant lymphoproliferative diseases (PTLD), renal cell carcinomas, and skin cancers [22]. An observational study by Kauffman and colleagues showed that mTOR-inhibitor use was associated with a 56\% reduction in the risk for de novo solid cancer after kidney transplantation [32]. A US database study showed that with 1 exception, the incidence of cancer was decreased by $26 \%$ with the use of sirolimus compared with nonsirolimus immunosuppression [33]. The data from the clinical trial, CONVERT study showed that (calcineurin inhibitor) CNI conversion to sirolimus compared to CNI continuation was associated with a significant reduction in the incidence of skin cancers and total malignancies in kidney transplant recipient $[\mathbf{3 4 , 3 5}]$. Hence, an immunosuppressant that inhibits both viral activation and oncogenesis would provide additional unique benefits to organ transplant recipients. Unfortunately, association between transplant outcomes and the effects of pretransplant viral serology and posttransplant mTor inhibitor regimens have not been widely explored. Therefore, using SRTR data on 61590 kidney transplants in the US from 2003 through 2013, we conducted this observational cohort study in order to investigate the risks for post-transplant patient death, graft loss and post-transplant malignancy associated with sirolimus regimens and pre-transplant viral serostatus of KTR. Our findings presented in this manuscript could provide the basis for utilizing baseline serology as an important factor to consider in drug selection and outcomes prognostication related to sirolimus regimens. 


\section{Patients and Methods}

This study which used data from the Scientific Registry of Transplant Recipients (SRTR) and was approved by the University of Florida Institutional review board. The SRTR system includes data on all donor, wait-listed candidates, and transplant recipients in the US, submitted by the members of the Organ Procurement and Transplantation Network (OPTN), and has been described elsewhere. The Health Resources and Services Administration provides oversight to the activities of the OPTN and SRTR contractors.

A retrospective cohort design was used to investigate outcomes associated with 2 common sirolimus regimens in relation to the pretransplant viral serostatus of adult kidney-only transplant recipient (KTR) in the United States from January 1, 2000 through December 31, 2013. KTR who survived the first transplant year free of cancer or graft loss, and met the inclusion criteria were included in the study. Follow-up started after the $12^{\text {th }}$ month of kidney transplant, until the earliest of the following: 1. End of fifth transplant year, 2. Re-transplantation, 3. Death, or 4. end of SRTR follow-up. Endpoints for this study included patient death, death-censored graft loss, and post-transplant malignancy (consisting of de novo tumors and posttransplant lymphoproliferative disorders censored for death or graft loss), (21). Analyses focused on the association of outcomes to the interactions between $\mathrm{HBc}, \mathrm{HCV}$, EBV or CMV pretransplant antibody serostatus and sirolimus and mycophenolate with/without steroid (SRL+MPA) or sirolimus and tacrolimus with/without steroid (SRL+Tac) regimen. 
Based on SRTR files, the following pretransplant viral antibody serostatus classified as positive (+) or negative (-), were included for analysis in this study: Hepatitis B core (HBc), Hepatitis C virus (HCV), Cytomegalovirus (CMV), and Epstein Barr Virus (EBV).

KTR cohorts were formed based on the immunosuppression regimen continuously used for a minimum duration of 6 months immediately before and including the twelfth-month posttransplant follow-up. Based on the SRTR immunosuppression follow-up files, KTR were on the same regimen at discharge, $6^{\text {th }}$ month and $12^{\text {th }}$ month follow-up, or only at the $6^{\text {th }}$ month and12th month follow-up, with a different regimen at discharge. The study-cohorts consisted of KTR on sirolimus and mycophenolate mofetil or sodium with/without steroids (SRL+MPA) and sirolimus and tacrolimus with/without steroids (SRL+Tac) regimens. The reference or control cohort consisted of KTR on tacrolimus and mycophenolate with/without steroids (Tac+MPA). Use of steroids was disregarded in cohort stratification, but was corrected for in the multivariable models. Due to their distinctly different management requirements, recipients with positive human immunodeficiency virus (HIV) serology were excluded from this study Also excluded from this study were KTR who had a malignancy, died or lost their allograft within the first 12 months of transplant; recipients of nonrenal organ transplant; and, those with missing data on baseline serology or maintenance immunosuppression at pertinent follow-up periods.

From among the KTR who would have met the study inclusion criteria except for the duration of sirolimus regimen use specified above, the following cohorts were formed for additional analyses of outcomes: 1 . KTR who were on a sirolimus regimen at discharge and the $6^{\text {th }}$ month follow-up only, with different regimens at $12^{\text {th }}$ month follow-up; and, 2 . KTR who were on a 
sirolimus regimen either at discharge or the $6^{\text {th }}$ month follow-up only with different regimen/s at other relevant follow-up times, or at discharge and the $12^{\text {th }}$ month follow-up, but not at the $6^{\text {th }}$ month follow-up.

Statistical Analysis

Baseline cohort characteristics were presented using means with standard deviations for continuous variables and proportions (percentages) for categorical variables. Differences in means and proportions were compared with the Student's t test and Chi-square test, respectively. The viral serology statuses, and sirolimus regimens, and literature-based outcomes-specific risk factors (36), were used as independent co-variates in the main and sirolimus regimen $\mathrm{x}$ viral serostatus interaction Cox multivariable regression models (subsequently termed Cox models) for patient death, death-censored graft loss and malignancy occurrence censored for death or graft loss $(\mathbf{2 1}, \mathbf{3 7 - 4 0})$ in the 4 years following the posttransplant month-12 follow-up, i.e. 5 years posttransplant. A co-variate for year of transplant after 2009 was included to adjust for any confounding influence on the study outcomes of the clinicians' prescribing behavior as result of a Federal Drug Administration alert to all US physicians on June 2009 regarding the increased mortality associated with conversion of calcinuerin inhibitor-based immunosuppression to sirolimus [41]. Additional Cox regression analyses with the same outcomes and covariates as in the main study cohorts were performed on KTR who were on SRL+MPA or SRL+Tac within the first transplant year but did not meet the required duration of treatment specified for inclusion in the study. The unadjusted odds ratio for death in 5 years, after 1 -year conditional survival, for each specific cause (infections, cardio-vascular diseases, malignancies or any organ failure) were compared between the sirolimus regimens and the standard Tac+MPA regimen. In all Cox 
multivariable analyses, co-variates other than drug regimens or viral serostatuses were selected based on previously published studies [36]. Conformity of the Cox models with the proportionality of hazards assumption were verified by visually inspecting the complementary log-log survival plots for the primary explanatory variables and examining the Schoenfeld residual plots. The risk factors predictive of the continuous use of either SRL+MPA or SRL+Tac regimens vs. Tac+MPA in the study treatment period were assessed by multivariable logistic regression analysis. Results of the Cox or logistic regression models were reported as hazard ratio $(\mathrm{HR})$ or odds ratio (OR), respectively with the $95 \%$ confidence interval (CI) for each covariate. All analyses were performed using SAS software, version 9.2 (SAS Institute, Inc., Cary, NC, USA). Statistical significance was based on a p-value $<.05$ and all confidence intervals used a $95 \%$ threshold.

\section{Results}

\section{$\underline{\text { Study population and demographics }}$}

We studied 61590 adult kidney transplant cases from Jan 1, 2000 through December 31, 2013 with conditional malignancy-free, patient and graft survival at 1 year. 2659 (4.3\%) were on SRL+MPA, 2167 (3.5\%) on SRL+Tac and 56764 (92.2\%) on Tac+MPA. The baseline characteristics of the study cohorts are shown in Table 1. The Hepatitis B core and CMV antibody seropositivity rates differed statistically among the groups but there were no significant differences in the antibody seropositivity to $\mathrm{HCV}$ and EBV among the cohorts, (Table 1). Utilization of $\mathrm{T}$ cell-depleting antibodies for induction was highest in the Tac+MPA cohort, while use of maintenance corticosteroids was lowest in the SRL+Tac cohort (Table 1). 
Predictors of being maintained on sirolimus for at least 6 months immediately before and including the first transplant year

The likelihood of being maintained on SRL+MPA or SRL+Tac instead of Tac+MPA was increased with African American recipient race and decreased with the following factors: CMV+ serostatus, older age, PRA>20\%, transplantation year after 2009 and alemtuzumab induction (Table 2). Predictors of being maintained on SRL+MPA versus the other regimens were ECD kidney, coronary artery disease and male sex of transplant recipient. Obesity is associated with a lower likelihood of being maintained on SRL+Tac than the other regimens. Between the 2 sirolimus regimens, the likelihood of being maintained on SRL+MPA instead of SRL+Tac was increased with the following factors: obesity, transplant after year 2009, alemtuzumab induction or first as opposed to repeat transplant (Table 2).

\section{Sirolimus regimen and viral serology as independent risk factors for outcomes}

The 5-year mortality, graft loss and posttransplant malignancy risks associated with the SRL+MPA and SRL+Tac regimens were analyzed with the Cox model using the Tac+MPA regimen as reference (Fig. 1,2,3). The mortality risks were higher in the SRL+Tac and SRL+MPA cohorts compared with the reference group

$[(\mathrm{HR}=1.41,95 \% \quad \mathrm{CI}=1.23-1.60 ; \mathrm{p}<.001) \quad$ and $\quad(\mathrm{HR}=1.59,95 \% \quad \mathrm{CI}=1.38-1.83 ; \mathrm{p}<.001)$ respectively]. Compared with a negative serostatus, a positive HCV serostatus was associated with a higher mortality risk $(\mathrm{HR}=1.53,95 \% \mathrm{CI}=1.35-1.74 ; \mathrm{p}<.001)$, while a positive $\mathrm{EBV}$ or CMV serostatus was associated with a lower mortality risk $(\mathrm{HR}=0.85,95 \% \mathrm{CI}=0.77-0.94$; $\mathrm{p}<.001)$ and $(\mathrm{HR}=0.89,95 \% \mathrm{CI}=0.83-0.96 ; \mathrm{p}=.005)$; respectively $)$, and a positive $\mathrm{HBc}$ serostatus 
was not associated with a significantly different mortality risk $(\mathrm{HR}=0.93,95 \% \mathrm{CI}=0.83-1.05$; $\mathrm{p}=.23$ ). The 5-year cause-specific death rates in the immunosuppression cohorts are depicted in Figure 4. Cardiovascular disease was the most common cause of death; and the unadjusted risks of death associated with the sirolimus regimens were not different from the reference regimen in any of the specific causes analyzed (organ failure, cardio-vascular disease, infection and malignancy), (Figure 4).

Figure 2 shows that the SRL regimens were associated with higher 5-year death-censored graft loss (DCGL) risk than the Tac+MPA regimen [(SRL+MPA: HR=1.41, 95\% CI=1.24-1.60; $\mathrm{p}<.001)$ and $(\mathrm{Tac}+\mathrm{SRL}: \mathrm{HR}=1.38,95 \% \mathrm{CI}=1.21-1.57 ; \mathrm{p}<.001)]$. Compared with a negative serostatus, a positive HCV serostatus was associated with a higher risk of graft loss $(\mathrm{HR}=1.50$, 95\% CI=1.33-1.70; $\mathrm{p}<.001)$. The relative risks for DCGL associated with other viral serostatuses were not significant as shown in Fig. 2.

Relative to the Tac+MPA regimen, the risk of death or graft loss-censored posttransplant malignancy (PTM) was $20 \%$ lower with the SRL+MPA regimen and was not significantly different with the SRL+Tac regimen $[(\mathrm{HR}=0.80,95 \% \mathrm{CI}=0.65-0.98 ; \mathrm{p}=.03)$ and $(\mathrm{HR}=0.82$, 95\% CI=0.65-1.03; $\mathrm{p}=.09$ ); respectively] Compared with a negative serostatus, a positive HCV serostatus was associated with a higher risk of $\mathrm{PTM}(\mathrm{HR}=1.24,95 \% \mathrm{CI}=1.02-1.52 ; \mathrm{P}=.02)$, while a positive $\mathrm{HBc}$ or $\mathrm{CMV}$ serostatus was associated with a lower risk of PTM [(HR=0.80 95\% $\mathrm{CI}=0.68-0.95 ; \mathrm{p}<.01)$ and $(\mathrm{HR}=0.82,95 \% \mathrm{CI}=0.76-0.90 ; \mathrm{p}<.001)$, respectively], (Figure 3). As depicted in Figure 3, ATG or alemtuzumab induction was associated with a higher PTM risk than basiliximab induction $(\mathrm{HR}=1.27,95 \% \mathrm{CI}=1.15-1.40 ; \mathrm{p}<.001)$ and $[(\mathrm{HR}=1.30,95 \%$ 
$\mathrm{CI}=1.10-1.54 ; \mathrm{p}=.002)$, respectively]. A steroid-containing maintenance regimen was associated with a higher risk of PTM than a steroid-free regimen $(\mathrm{HR}=1.14,95 \% \mathrm{CI}=1.04-1.25 ; \mathrm{p}=.003)$.

\section{Sirolimus regimen and viral serology interaction as risk factor for outcomes}

After determining the adjusted risks independently associated with each of the sirolimus regimens and viral serology statuses, multiple Cox models were constructed to analyze the risks for outcomes associated with the interaction between baseline viral serostatus and sirolimus regimen (Figures 5, 6, 7). The Tac+MPA regimen was used as the reference or control in all of the analyses.

\section{$\underline{\text { Mortality Risk }}$}

Figure 5 depicts that compared with control, most sirolimus regimen-viral serostatus interactions were associated with statistically higher risks for patent death in 5 years, except in: SRL regimen in $\mathrm{HCV}+\mathrm{KTR}[(\mathrm{SRL}+\mathrm{MPA}: \mathrm{HR}=1.50,95 \% \mathrm{CI}=0.93-2.26), \quad(\mathrm{SRL}+\mathrm{Tac}: \mathrm{HR}=1.41,95 \%$ $\mathrm{CI}=0.84-2.27)]$; $\mathrm{SRL}+\mathrm{MPA}$ in $\mathrm{HBc}+\mathrm{KTR}(\mathrm{HR}=1.38,95 \% \mathrm{CI}=0.84-2.25)$ and $\mathrm{SRL}+\mathrm{Tac}$ in $\mathrm{EBV}-$ KTR $(\mathrm{HR}=1.41,95 \% \mathrm{CI}=0.96-2.06)$.

\section{$\underline{\text { Death-censored graft loss risk }}$}

Regardless of concomitant pretansplant viral serostatus, most sirolimus regimens were associated with higher risk for DCGL than control except with SRL+Tac in HBc+, HCV+, and CMVtransplant recipients (Figure 5). 


\section{Post-transplant malignancy risk, censored for death or graft-loss}

Relative to the reference regimen (Tac+MPA), the 5-year risk of posttransplant malignancy (PTM) was lower with SRL+MPA, not SRL+Tac in KTR with HBc-, HCV-, EBV- or CMVserostatus pre-transplant; (Fig. 7). The highest de novo PTM risk reduction point estimate of 73 \% was seen in EBV- recipients on SRL+MPA $(\mathrm{HR}=0.27,95 \% \mathrm{CI}=0.10-0.72)$, followed by $39 \%$ in CMV- recipients on SRL+MPA ( $\mathrm{HR}=0.61,95 \% \mathrm{CI}=0.43-0.88)$. No risk reduction for PTM was seen in KTR with positive viral serostatus pretransplant and placed on either SRL+MPA or SRL+Tac (Figure 7).

\section{Outcomes in KTR with sirolimus use at other periods in first transplant year}

In KTR who received SRL+MPA or SRL+Tac within the first transplant year, albeit outside of the study periods above; the adjusted relative risk for death was 3 times higher in KTR on SRL+MPA at discharge and $6^{\text {th }}$ month follow-up only compared with KTR on SRL+MPA or SRL+Tac in the study periods, $[\mathrm{HR}=4.29,95 \% \mathrm{CI}=2.31-7.97$ vs. $\mathrm{HR}=1.41,95 \% \mathrm{CI}=1.23-1.60$ or $\mathrm{HR}=1.53$, 95\% $\mathrm{CI}=1.35-1.74$, respectively], [Figure 8]. Due to database and sample size limitations, we were unable to analyze the factors related to the switch or discontinuation of sirolimus regimens.

\section{Discussion}

Our study of 62315 adult recipients of kidney transplants over a 14-year period based on the United States SRTR focused on the association between 5-year transplant outcomes and baseline Hepatitis B core, Hepatitis C, CMV and EBV serostatus of kidney allograft recipients with 1year conditional cancer and graft-loss free survival exposed to 2 sirolimus regimens in the 6 or 
more months immediately before and including the first transplant year anniversary. We also examined factors predictive of the sustained use of sirolimus within the period mentioned. The primary results of our study demonstrated that the interaction between pre-transplant viral serostatus and posttransplant sirolimus regimen [(SRL+MPA or SRL+Tac) maintained for at least 6 months into the first transplant year], were associated with varying posttransplant malignancy risks. Negative $\mathrm{HBc}, \mathrm{HCV}, \mathrm{EBV}$ or $\mathrm{CMV}$ serostatus was associated with a risk reduction for de novo cancer in KTR maintained on SRL+MPA, not SRL+Tac. A positive (HBc, $\mathrm{HCV}, \mathrm{EBV}$ or CMV) serostatus was not associated with a significant difference in de novo cancer risk with either SRL regimens, SRL+MPA or SRL+Tac (versus the reference regimen). With few exceptions, regardless of their baseline viral serostatus, mortality and graft loss risks were higher in KTR maintained on sirolimus regimens compared to those maintained on Tac+MPA Our findings could enable the use of pretransplant viral antibody serostatus in the decision-making process regarding the use of SRL+MPA, er SRL+Tac, or Tac+MPA as maintenance regimen in kidney transplant rejection prophylaxis. For patients already on sirolimus regimens, knowledge of the interaction between the specific regimen and baseline viral serostatus may help in the prognostication of for transplant outcomes.

The overall Cox model for including all 62315 recipients showed that sirolimus-containing regimens were associated with higher risks of patient death. This is consistent with the findings in a meta-analysis that included 21 randomized controlled trials with 5963 patients [35]. In that report, any sirolimus regimen was associated with a $43 \%$ increased risk of death; whereas, in our current retrospective study involving 4826 patients, stratified analysis of sirolimus regimens showed that the risk of death relative to the reference regimen was higher by $54 \%$ with 
SRL+Tac, and by $37 \%$ with SRL+MPA. Due to database limitation, we were unable to test whether the prodiabetic, prodyslipidemic, and nephrotoxic complications of the combined SRL+Tac regimen could have contributed to the higher mortality in KTR treated with the regimen especially in the HCV-positive KTR [31, 42-55]. Our findings in kidney transplants are consistent with the finding of Wagner et al. in liver transplants wherein SRL+MPA was associated with a more favorable outcome than SRL+Tac in $\mathrm{HCV}+$ patients

[Figure 5], [53]. In another study, Luan, et al showed that in HCV seropositive KTR, mycophenolate lowered, while tacrolimus seemed to have increased the risk for patient mortality [16]. The reduced risk of mortality associated with a positive CMV or EBV serostatus in the main Cox model was likely driven by the large size of the Tac+MPA cohort which comprised 92\% of the sample [Table 1]. This is supported by the stratified Cox analyses results that showed lower mortality risk with Tac+MPA than with any of the sirolimus regimens regardless of the concomitant CMV or EBV serostatus of the KTR [Fig. 1].

The main Cox models showed that the 2 sirolimus regimens were associated with a higher risks of death-censored graft loss than Tac+MPA. The Cox models with interactions showed that regardless of the viral serostatus of KTR, SRL-containing regimens were as sociated with higher risk of graft loss than Tac+MPA; except with SRL+Tac in HBc+ or HCV+KTR. With the recent introduction of more efficacious regimens for $\mathrm{HCV}$ treatment, the implications of our findings may become limited to KTR with contraindications or unsuccessful response to HCV treatment [56]. 
According to our analysis of the CONVERT trial adverse reaction data [57], sirolimus regimens were associated with a lower risk of malignancy versus non-sirolimus regimens at the 2-year follow-up [crude risk ratio 0.35 , $(95 \% \mathrm{CI}=0.20-0.59)$ ]. A retrospective database analysis by Kauffman, et.al. showed that sirolimus was associated with a de novo cancer risk reduction of 0.39 (95\% CI=0.24-0.64), [32]. In our study, the risk reduction for cancer was significant at $20 \%$ for SRL+MPA but not for SRL+Tac [(SRL+MPA: HR=0.80, 95\% CI=0.65-0.98) and (SRL+TAC:HR $=0.82,95 \% \mathrm{CI}=0.65-1.03)]$. Our study differed from the 2 preceding studies in its larger sample size, its stratification of SRL regimens into SRL+MPA and SRL+Tac, and its analysis of interactions between SRL and viral serology. Compared to the study of Kauffman et al., we analyzed outcomes based on longitudinal immunosuppression data at 3 points after transplant and not on discharge information alone and we studied SLR+MPA, not SRL+ calcineurin inhibitor only [17].

We have found a significantly higher risk of death in KTR who were on sirolimus at discharge and 6th month (but the regimen was not successfully continued to the $12^{\text {th }}$ month of transplant) compared with KTR whose SRL regimens were successfully continued to the $12^{\text {th }}$ month of transplant after initial use at or before discharge or $6^{\text {th }}$ month follow-up [Figure 8]. As the factors that affected the decision to discontinue the sirolimus regimens were not reported in SRTR, we can only hypothesize that discontinuation of sirolimus regimens may have indicated complications and/or poor patient conditions that increased the risk of death.

Our study provides a unique perspective in the consideration of sirolimus regimens in kidney retransplants by highlighting the important relationships between transplant outcomes and the 
interactions between the baseline viral serostatus and posttransplant SRL regimens of KTR. Our study limitations include those inherent in an observational analysis [58], and lack of information on the following: tacrolimus and sirolimus blood levels, incidence of posttransplant viral infections and treatment given. Due to the underreporting of specific malignancy types to SRTR (59), we used the standard analysis files' aggregated data on de novo malignancy and PTLD. Therefore, our report cannot provide sufficiently powered analyses on the relationships between specific malignancy types, sirolimus regimens and transplant outcomes. Despite its shortcomings, we used the SRTR as our data source relying on the established acceptance of this database in well-regarded transplantation publications $(10,21,32,39,60)$.

In conclusion, our retrospective study demonstrated that compared with standard Tac+MPA immunosuppression, the lower risk of malignancy associated with sirolimus regimen is seen with SRL+MPA, not with SRL+Tac in KTR with negative pretransplant antibody serology to Hbc, $\mathrm{HCV}$, EBV or CMV; neither sirolimus regimen was associated with a different malignancy risk in KTR with positive pretransplant antibody serology to any of the foregoing viruses. With a few exceptions, a sirolimus-containing regimens were associated with higher risks of patient death and death-censored graft loss than the Tac+MPA regimen regardless of the recipient's baseline viral serostatus. Our findings may be informative in planning posttransplant immunosuppression with sirolimus-containing regimens and in prognosticating 5-year outcomes in KTR already receiving SRL regimens. 


\section{Acknowledgments}

The data reported here have been supplied by the Minneapolis Medical Research Foundation as the contractor for the SRTR. The interpretation and reporting of these data are the responsibility of the authors and in no way should be seen as an official policy of or interpretation by the SRTR or the U.S. Government. 


\section{References}

1. Weikert BC, Blumberg EA. Viral infection after renal transplantation: surveillance and management. Clin J Am Soc Nephrol. 2008 ;3 Suppl 2: S76-86.

2. Cukuranovic J, Ugrenovic S, Jovanovic I, Visnjic M, Stefanovic V. Viral infection in renal transplant recipients. Scientific World Journal. 2012; 2012:820621

3. Kotton CN, Fishman JA. Viral infection in the renal transplant recipient. J Am Soc Nephrol. $2005 ; 16(6): 1758-74$.

4. Boubenider S, Hiesse C, Marchand S, Hafi A, Kriaa F, Charpentier B. Post-transplantation polyomavirus infections. J Nephrol. 1999;12(1):24-9.

5. Sagedal S, Nordal KP, Hartmann A, , et al. The impact of cytomegalovirus infection and disease on rejection episodes in renal allograft recipients. Am J Transplant. 2002 Oct; 2(9):850-6.

6. Gutierrez-Dalmau A, Campistol JM. Immunosuppressive therapy and malignancy in organ transplant recipients: a systematic review. Drugs. 2007; 67(8):1167-98.

7. Desai R, Collett D, Watson CJE, Johnson PJ, Moss P, Neuberger J. Impact of Cytomegalovirus on Long-term Mortality and Cancer Risk After Organ Transplantation. Transplantation. 2015 Sep; 99(9):1989-94.

8. Sagedal S, Hartmann A, Nordal KP, et al. Impact of early cytomegalovirus infection and disease on long-term recipient and kidney graft survival. Kidney Int. $2004 \mathrm{Jul}$; 66(1):32937.

9. Freeman RB. The "indirect" effects of cytomegalovirus infection. Am J Transplant. 2009 Nov; 9(11):2453-8. 
10. Dharnidharka VR, Lamb KE, Gregg JA, Meier-Kriesche H-U. Associations between EBV serostatus and organ transplant type in PTLD risk: an analysis of the SRTR National Registry Data in the United States. Am J Transplant. 2012 ; 12(4):976-83.

11. Shahinian VB, Muirhead N, Jevnikar AM, et al. Epstein-Barr virus seronegativity is a risk factor for late-onset posttransplant lymphoroliferative disorder in adult renal allograft recipients. Transplantation. 2003 ; 75(6):851-6.

12. Bamoulid J, Courivaud C, Coaquette A, et al. Subclinical Epstein-Barr virus viremia among adult renal transplant recipients: incidence and consequences. Am J Transplant. 2013 ; 13(3):656-62.

13. Lezaic V, Visnja L, Stosovic M, et al. Hepatitis B and hepatitis C virus infection and outcome of hemodialysis and kidney transplant patients. Ren Fail. 2008; 30(1):81-7.

14. O’ Riordan, A, Agarwal, K, Kon, S, Macdougall, I, Donohoe. Reactivation of hepatitis B virus infection in renal transplant recipients. www.britishrenal.org/BritishRenalSociety/files/2e/2e809ba0-f18e accessed 3/7/2016.

15. Lin H-H, Huang C-C, Huang J-Y, et al. Impact of HCV infection on first cadaveric renal transplantation, a single center experience. Clin Transplant. 2004 ; 18(3):261-6.

16. Luan FL, Schaubel DE, Zhang H, et al. Impact of immunosuppressive regimen on survival of kidney transplant recipients with hepatitis C. Transplantation. 2008 Jun 15; 85(11):1601-6.

17. Morton LM, Gibson TM, Clarke CA, Lynch CF, Weisenburger DD, Engels EA. Hepatitis B or $\mathrm{C}$ virus infection and risk of non-Hodgkin lymphoma among solid organ transplant recipients. Haematologica. 2014 May; 99(5):70-3.

18. Morath C, Arns W, Schwenger V, et al. Sirolimus in renal transplantation. Nephrol Dial Transplant. 2007 ; 22 Suppl 8: viii61-5. 
19. Gatault P, Lebranchu Y. Conversion to mTOR-inhibitor-based immunosuppression: which patients and when? Transplant Res. 2013 ; 2(Suppl 1): S3.

20. González E, Andrés A, Polanco N, et al. Everolimus represents an advance in immunosuppression for patients who have developed cancer after renal transplantation. Transplant Proc. 2009 ; 41(6):2332-3.

21. Bustami RT, Ojo AO, Wolfe RA, et al. Immunosuppression and the risk of post-transplant malignancy among cadaveric first kidney transplant recipients. Am J Transplant. 2004 ; 4(1):87-93.

22. Kahan BD, Knight R, Schoenberg L, et al. Ten years of sirolimus therapy for human renal transplantation: the University of Texas at Houston experience. Transplant Proc. 2003 ; 35(3 Suppl):25S - 34S.

23. Shertz CA, Cardenas ME. Exploiting and subverting Tor signaling in the pathogenesis of fungi, parasites, and viruses. PLoS Pathog. 2011 Sep; 7(9): e1002269.

24. Krams SM, Martinez OM. Epstein-Barr virus, rapamycin, and host immune responses. Curr Opin Organ Transplant. 2008; 13(6):563-8.

25. Luan FL, Hojo M, Maluccio M, et al. Rapamycin Blocks Tumor Progression: Unlinking Immunosuppression from Antitumor Efficacy. Transplantation 2002; 73: 1565-72.

26. Back JH, Kim AL. The expanding relevance of nuclear mTOR in carcinogenesis. Cell Cycle. 2011 Nov 15; 10(22):3849-52.

27. Koehl GE, Andrassy J, Guba M, et al. Rapamycin protects allografts from rejection while simultaneously attacking tumors in immunosuppressed mice. Transplantation. 2004 ; 77(9):1319-26. 
28. Law BK. Rapamycin: an anti-cancer immunosuppressant? Crit Rev Oncol Hematol. 2005 ; $56(1): 47-60$.

29. Belliere J, Kamar N, Mengelle C, et al. Pilot conversion trial from mycophenolic acid to everolimus in ABO-incompatible kidney-transplant recipients with BK viruria and/or viremia. Transpl Int. 2016 Mar; 29(3):315-22.

30. Baid-Agrawal S, Pascual M, Moradpour D, Somasundaram R, Muche M. Hepatitis C virus infection and kidney transplantation in 2014: what's new? Am J Transplant. 2014 Oct; 14(10):2206-20.

31. Brennan DC, Aguado JM, Potena L, Jardine AG, Legendre C, Säemann MD, et al. Effect of maintenance immunosuppressive drugs on virus pathobiology: evidence and potential mechanisms. Rev Med Virol. 2013 ; 23(2):97-125.

32. Kauffman HM, Cherikh WS, Cheng Y, Hanto DW, Kahan BD. Maintenance immunosuppression with target-of-rapamycin inhibitors is associated with a reduced incidence of de novo malignancies. Transplantation. 2005 ; 80(7):883-9.

33. Yanik EL, Gustafson SK, Kasiske BL, et al. Sirolimus use and cancer incidence among US kidney transplant recipients. Am J Transplant. 2015 ; 15(1):129-36.

34. Gatault P, Lebranchu Y. Conversion to mTOR-inhibitor-based immunosuppression: which patients and when? Transplant Res. 2013 ; 2(Suppl 1): S3.

35. Flechner S, Friend P, Campistol J, Weir M, Diekmann F, Russ G. De novo immunosuppression with mammalian target of rapamycin inhibitors and posttransplantation malignancy in focus. Transplant Proc. 2009 ; 41(6 Suppl): S42-4. 
36. Bagley SC, White H, Golomb BA. Logistic regression in the medical literature: standards for use and reporting, with particular attention to one medical domain. Clin Epidemiol. 2001; 54: 979-985.

37. Kasiske, B, Snyder J, Gilbertson D, Wang C. Cancer after kidney transplantation in the United States. Am J Transplant. 2004; 4:905-913.

38. Ju MK, J DJ, Kim SJ, et al. Chronologically different incidences of post-transplant malignancies in renal transplant recipients: single center experience. Transplant International. 2009; 2(6): 644-653.

39. Cherikh Ws, Kauffman HM, McBride MA, Maghirang J, Swinnen LJ, Hanto DW. Association of the type of induction immunosuppression with posttransplant lymphoproliferative disorder, graft survival, and patient survival after primary kidney transplantation. Transplantation 2003 ; 76(9): 1289-1293.

40. Kidney Disease: Improving Global Outcomes (KDIGO) Transplant Work Group. KDIGO clinical practice guideline for the care of kidney transplant recipients. Am J Transplant. 2009; 9 (Suppl 3): S1-S157.

41. 36. Information for Healthcare Professionals: Sirolimus (marketed as Rapamune) FDA ALERT [06/11/2009]:http://www.fda.gov/Drugs/DrugSafety/PostmarketDrugSafetyInformationforP atientsandProviders/DrugSafetyInformationforHeathcareProfessionals/ucm165015.htm Accessed 05/08/2016.

42. Knoll GA, Kokolo MB, Mallick R, et al. Effect of sirolimus on malignancy and survival after kidney transplantation: systematic review and meta-analysis of individual patient data. $B M J$. 2014; 349: g6679. 
43. Subherwal S, Patel MR, Kober L, et al. Peripheral artery disease is a coronary heart disease risk equivalent among both men and women: results from a nationwide study. Eur J Prev Cardiol. 2015 ;22(3):317-25.

44. Stack AG, Bloembergen WE. Prevalence and clinical correlates of coronary artery disease among new dialysis patients in the United States: a cross-sectional study. J Am Soc Nephrol. 2001; 12(7):1516-23.

45. den Dekker MAM, van den Dungen JJ a. M, Tielliu IFJ, Tio RA, et al. Prevalence of severe subclinical coronary artery disease on cardiac CT and MRI in patients with extra-cardiac arterial disease. Eur J Vasc Endovasc Surg. 2013; 46(6):680-9.

46. Marcén R. Immunosuppressive drugs in kidney transplantation: impact on patient survival, and incidence of cardiovascular disease, malignancy and infection. Drugs. 2009; 69(16):2227-43.

47. Sampaio MS, Cho YW, Shah T, Bunnapradist S, Hutchinson IV. Association of immunosuppressive maintenance regimens with posttransplant lymphoproliferative disorder in kidney transplant recipients. Transplantation. 2012 ; 93(1):73-81.

48. Murakami N, Riella LV, Funakoshi T. Risk of metabolic complications in kidney transplantation after conversion to mTOR inhibitor: a systematic review and meta-analysis. Am J Transplant. 2014 Oct; 14(10):2317-27.

49. Johnston O, Rose CL, Webster AC, Gill JS. Sirolimus is associated with new-onset diabetes in kidney transplant recipients. J Am Soc Nephrol. 2008 Jul; 19(7):1411-8.

50. Mason AL, Lau JY, Hoang N, Qian K, Alexander GJ, Xu L, et al. Association of diabetes mellitus and chronic hepatitis C virus infection. Hepatology. 1999 ; 29(2):328-33. 
51. Antonelli A, Ferri $C$, Fallahi $P$, et al. Hepatitis $C$ virus infection: evidence for an association with type 2 diabetes. Diabetes Care. 2005 ; 28(10):2548-50.

52. Hammerstad SS, Grock SF, Lee HJ, Hasham A, Sundaram N and Tomer Y (2015) Diabetes and hepatitis C: a two-way association. Front. Endocrinol. 6:134. doi:

10.3389/fendo.2015.00134

53. Wagner D, Kniepeiss D, Silvia S, et al Sirolimus has a potential to influent viral recurrence in HCV positive liver transplant candidates. Int Immunopharmacol. 2010 ;10(8):990-3.

54. Bloom RD, Lake JR. Emerging issues in hepatitis $C$ virus-positive liver and kidney transplant recipients. Am J Transplant. 2006 ; 6(10):2232-7.

55. Larson TS, Dean PG, Stegall MD, et al Complete avoidance of calcineurin inhibitors in renal transplantation: a randomized trial comparing sirolimus and tacrolimus. Am J Transplant 2006, 6:514-52.

56. Weikert BC, Blumberg EA. Viral infection after renal transplantation: surveillance and management. Clin J Am Soc Nephrol. 2008 ; 3 Suppl 2: S76-86.

57. Schena FP, Pascoe MD, Alberu J, del Carmen Rial M, et al. Conversion from calcineurin inhibitors to sirolimus maintenance therapy in renal allograft recipients: 24-month efficacy and safety results from the CONVERT trial. Transplantation. 2009 ; 87(2):233-42.

58. Kaplan B, Schold J, Meier-Kriesche H-U. Overview of large database analysis in renal transplantation. Am J Transplant. 2003 ; 3(9):1052-6

59. Yanik EL, Nogueira LM, Koch L, et al. Comparison of cancer diagnoses between the US solid organ transplant registry and linked central cancer registries. [published online ahead of print April $7^{\text {th }}$, 2016]. Am J Transplant. doi: 10.1111/ajt.13818. 
60. Quinlan SC, Pfeiffer RM, Morton LM, Engels EA. Risk factors for early-onset and late-onset post-transplant lymphoproliferative disorder in kidney recipients in the United States. Am J Hematol. 2011 ;86(2):206-9. 
FIGURE LEGEND

Figure 1. 5-Year Patient Mortality, Main Cox Model

Figure 2. 5-Year Death-Censored Graft Loss, Main Cox Model

Figure 3. 5-Year Malignancy Risk Factors, Main Cox Model

Figure 4. 5-Year Cause Specific Crude Death Rates in Cohorts with 1 Year Conditional Survival

Figure 5. 5-Year Risk for Patient Death, Viral Serostatus-Sirolimus Interaction Cox Models

Figure 6. 5-Year Risk for Death-Censored Graft Loss, Viral Serostatus-Sirolimus Interaction Cox Models

Figure 7. 5-Year Risk for Malignancy, Viral Serostatus-Sirolimus Interaction Cox Models

Figure 8. 5-Year Outcomes Associated with Different Durations of Sirolimus Regimen Use in the First Transplant Year 
Figure 15 Year Patient Mortality, Main Cox Model

\begin{tabular}{|c|c|c|c|c|c|}
\hline Risk Factors & HR & $95 \% \mathrm{Cl}$ & Risk Factors & HR & $95 \% \mathrm{Cl}$ \\
\hline SRL+MPA & 1.41 & $+1.23-1.60$ & Cardiovasc. Dis. & 1.43 & - $\quad 1.32-1.55$ \\
\hline SRL+Tac & 1.59 & - 1.38- 1.83 & Steroid & 1.24 & - $\quad 1.15-1.34$ \\
\hline Hepatitis B core Ab+ & 0.93 & 0.83- 1.05 & Transplant post-2009 & $0.31 *$ & $0.28-0.34$ \\
\hline Hepatitis C Ab+ & 1.53 & - 1.35- 1.74 & Diabetes Mellitus & 2.39 & $-2.06-2.77$ \\
\hline Epstein Barr Ab+ & 0.85 & 0.77- 0.94 & Glomerulonephritis & 1.26 & $-\quad 1.07-1.48$ \\
\hline Cytomegalovirus $\mathrm{Ab}+$ & 0.89 & $0.83-0.96$ & Hypertension & 1.65 & - 1.42- 1.93 \\
\hline ATG Induction & 0.91 & $0.84-0.99$ & Other CKD & 1.61 & $\rightarrow \quad 1.37-1.90$ \\
\hline Alemtuzumab Induction & 1.02 & $0.88-1.18$ & Age of Recipient in Yr. & 1.047 & $\quad 1.04-1.05$ \\
\hline Other Induction & 1.03 & $0.94-1.13$ & Dialysis History + & 1.59 & $1.42-1.78$ \\
\hline ECD Kidney & 1.73 & - 1.55- 1.93 & Prior kidney transplant & 1.40 & $1.24-1.58$ \\
\hline Standard Kidney & 1.33 & - $1.22-1.45$ & HLA $m m>3$ & 1.02 & $0.95-1.10$ \\
\hline PRA $>/=20 \%$ & 0.98 & 0.90- 1.07 & & $0 . \overline{1}$ & \\
\hline
\end{tabular}

Models adjusted for other covariates, not shown: Recipient African American Race $\mathrm{HR}=1.00,95 \% \mathrm{Cl}=0.92-1.08$; Recipient Gender $\mathrm{HR}=0.94,95 \% \mathrm{Cl}=0.88-1.02$ 
Figure 25 Year Death-Censored Graft Loss, Main Cox Model

\begin{tabular}{|c|c|c|c|c|c|}
\hline Risk Factors & HR & $95 \% \mathrm{Cl}$ & RiskFactors & $\mathrm{HR}$ & $95 \% \mathrm{Cl}$ \\
\hline SRL+MPA & 1.41 & 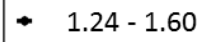 & Steroid & & $105-12$ \\
\hline SRL+Tac & 1.38 & - $\quad 1.21-1.57$ & Transplant post-2009 & $\begin{array}{l}1.14 \\
0.28\end{array}$ & $\begin{array}{l}1.05-1.24 \\
0.25-0.31\end{array}$ \\
\hline Hepatitis B core+ & 1.01 & $\quad 0.90-1.13$ & Diabetes Mellitus & $1.28^{\circ}$ & $\begin{array}{l}0.25-0.31 \\
1.35-1.87\end{array}$ \\
\hline Hepatitis C Ab+ & 1.50 & $+1.33-1.70$ & $\begin{array}{l}\text { Dlabetes IVIllitus } \\
\text { Glomerulonephritis }\end{array}$ & $\begin{array}{l}1.59 \\
1.43\end{array}$ & $\begin{array}{r}-1.35-1.87 \\
-\quad 122.168\end{array}$ \\
\hline Epstein Barr Ab + & 0.92 & $0.84-1.01$ & $\begin{array}{l}\text { Glomerulonephritis } \\
\text { Hypertension }\end{array}$ & $\begin{array}{l}1.43 \\
1.62\end{array}$ & $\begin{array}{l}1.22-1.68 \\
138-191\end{array}$ \\
\hline Cytomegalovirus $\mathrm{Ab}+$ & 1.03 & $0.96-1.11$ & $\begin{array}{l}\text { Hypertension } \\
\text { Other CKD }\end{array}$ & $\begin{array}{l}1.62 \\
1.52\end{array}$ & 1.38- 1.91 \\
\hline ATG & 0.96 & $0.88-1.05$ & $\begin{array}{l}\text { Other CKD } \\
\text { Age of Recipient in Yr. }\end{array}$ & $\begin{array}{l}1.52 \\
0.97\end{array}$ & 1.29- 1.79 \\
\hline Alemtuzumab & 1.17 & $1.00-1.35$ & Age of Recipient in Yr. & 0.97 & 0.969- 0.97 \\
\hline Other Induction & 1.08 & $0.99-1.19$ & Dialysis History + & 1.45 & - $1.30-1.62$ \\
\hline ECD Kidney & 2.15 & $* 1.92-2.42$ & Recipient, AA Race & 1.62 & - $1.50-1.75$ \\
\hline Standard Kidney & 1.25 & - $\quad 1.15-1.35$ & Prior kidney transplant & 1.09 & $0.98-1.21$ \\
\hline PRA $>/=20 \%$ & 1.11 & - $\quad 1.02-1.20$ & Recipient Female & 0.97 & $0.91-1.04$ \\
\hline HLA $m m>3$ & 1.09 & $1.02-1.18$ & Donor, AA Race & 1.30 & 1.19- 1.42 \\
\hline
\end{tabular}

Legend: SRL+MPA, sirolimus and mycophenolate; SRL+Tac, sirolimus and tacrolimus; 
Figure 35 Year Malignancy Risk Factors, Main Cox Model

\begin{tabular}{|c|c|c|c|c|c|}
\hline Risk Factors & HR & $95 \% \mathrm{Cl}$ & Risk Factors & $\mathrm{HR}$ & $95 \% \mathrm{Cl}$ \\
\hline SRL+MPA & 0.80 & $0.65-0.98$ & Transplant post-2009 & $0.31 \bullet$ & $0.28-0.34$ \\
\hline SRL+Tac & 0.82 & $0.65-1.03$ & Diabetes Mellitus & 0.70 & $0.60-0.79$ \\
\hline Hepatitis B core+ & 0.80 & $0.68-0.95$ & Glomerulonephritis & 1.05 & $0.92-1.20$ \\
\hline Hepatitis C Ab+ & 1.24 & $1.02-1.52$ & Hypertension & 0.80 & $0.70-0.92$ \\
\hline Epstein Barr Ab + & 0.98 & $0.86-1.10$ & Other CKD & 1.03 & $0.89-1.19$ \\
\hline Cytomegalovirus A + & 0.82 & $0.76-0.90$ & Age of Recipient in Yr. & 1.058 & $1.055-1.062$ \\
\hline ATG & 1.27 & $1.15-1.40$ & Dialysis History + & 0.77 & $0.70-0.84$ \\
\hline Alemtuzumab & 1.30 & $1.10-1.54$ & Recipient, AA Race & 0.60 & $0.53-0.67$ \\
\hline Other Induction & 0.88 & $0.77-0.99$ & Recipient Female & 0.75 & $0.69-0.82$ \\
\hline \multirow[t]{2}{*}{ Steroid-Maintained } & 1.14 & $1.04-1.25$ & Recipient BMI $\left(\mathrm{kg} / \mathrm{m}^{2}\right)$ & 1.03 & $0.95-1.13$ \\
\hline & & & & 0.1 & (10 \\
\hline
\end{tabular}

Legend: SRL+MPA, sirolimus and mycophenolate; SRL+Tac, sirolimus and tacrolimus; 
Figure 45 Year Cause-Specific Death Rates in Cohorts with Conditional 1 Year Survival

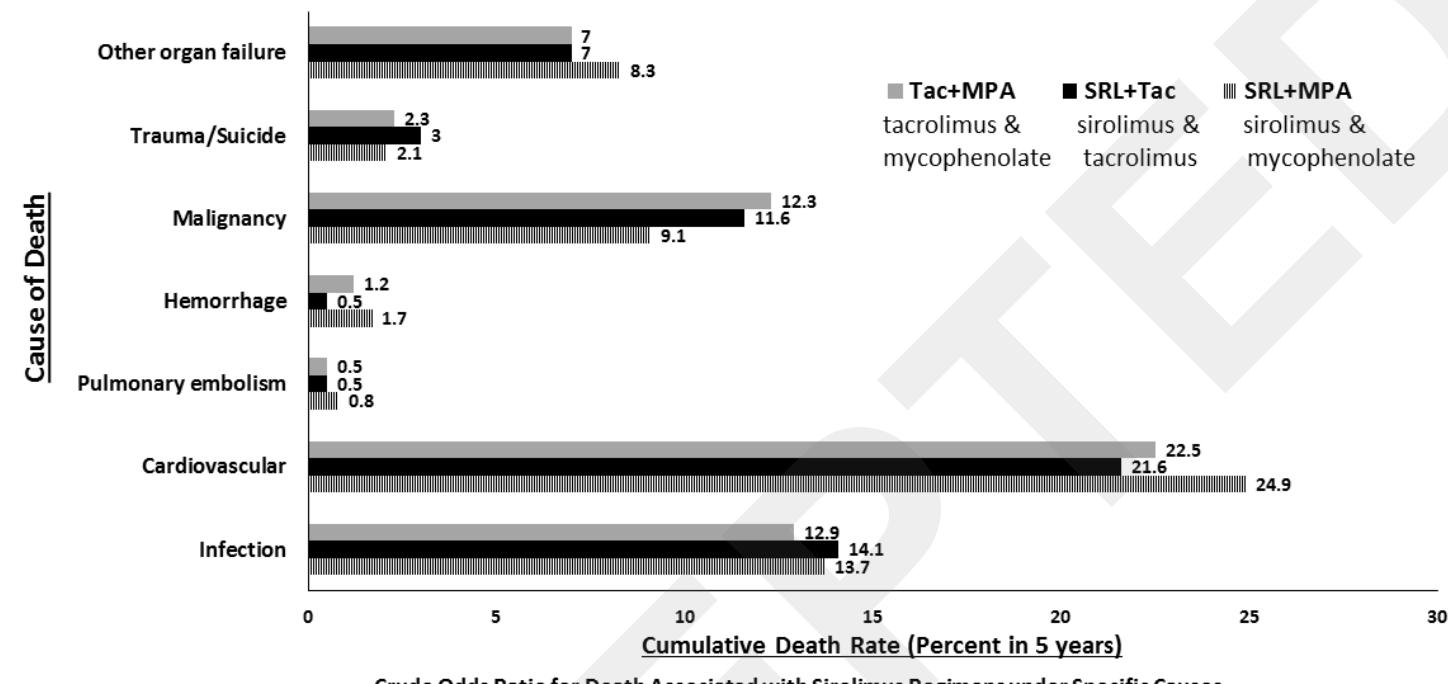

Crude Odds Ratio for Death Associated with Sirolimus Regimens under Specific Causes

\begin{tabular}{|c|c|c|c|c|c|c|}
\hline Regimen & 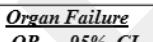 & $\frac{\text { Cardiovascular Dis. }}{0.050}$ & & $\frac{a n c y}{a}$ & & $\frac{t i o n s}{a s a^{\prime}}$ \\
\hline & OR $\quad 95 \% C I$ & OR $\quad 95 \% \mathrm{CI}$ & $O R$ & $95 \% C I$ & & $95 \% C I$ \\
\hline SRL + MPA (vs.Tac +MPA) & $1.22 \quad 0.74-2.01$ & $0.82-1.58$ & 0.76 & $0.47-1.23$ & 1.09 & $0.72-1.64$ \\
\hline SRL+Tac (vs. Tac +MPA) & $1.00 \quad 0.56-1.78$ & $0.65-1.38$ & 0.93 & $0.58-1.50$ & 1.08 & $0.69-1.67$ \\
\hline
\end{tabular}


Figure 55 Year Risk for Patient Death, Viral Serostatus-Sirolimus Interaction Cox Models

\begin{tabular}{|c|c|c|c|c|c|}
\hline Risk Factors & HR & $95 \% \mathrm{Cl}$ & Risk Factors & $\mathrm{HR}$ & $95 \% \mathrm{Cl}$ \\
\hline $\mathrm{HBC}^{\mathrm{a}}$ : Referent* & 1.00 & $1.00-1.00$ & EBV+ ': Referent* & 1.00 & $1.00-1.00$ \\
\hline SRL+MPA & 1.50 & $\begin{array}{r}1.003-226 \\
-0.93\end{array}$ & SRL+MPA & 1.37 & - $1.19-1.58$ \\
\hline SRL+Tac & 1.41 & $\begin{array}{r}0.53-2.20 \\
-0.84-2.27\end{array}$ & SRL+Tac & 1.62 & $-1.40-1.89$ \\
\hline HBc- a: Referent* & $\begin{array}{l}1.41 \\
1.00\end{array}$ & $-0.84-2.27$ & EBV- c: Referent* & 1.00 & $1.00-1.00$ \\
\hline SRL+MPA & $\begin{array}{l}1.00 \\
1.40\end{array}$ & $\begin{array}{l}1.00-1.00 \\
+120161\end{array}$ & SRL+MPA & 1.66 & $\rightarrow 1.19-2.31$ \\
\hline SRL+Tac & $\begin{array}{l}1.40 \\
1.61\end{array}$ & + $1.22-1.61$ & SRL+Tac & 1.41 & $0.96-2.06$ \\
\hline HCV+ b: Referent* & $\begin{array}{l}1.61 \\
1.00\end{array}$ & * $1.39-1.86$ & CMV+d: Referent* & 1.00 & $1.00-1.00$ \\
\hline SRL+MPA & 1.38 & $-\quad 0.84-2.25$ & SRL+MPA & 1.38 & - $\quad 1.18-1.62$ \\
\hline SRL+Tac & 2.02 & $-1.24-3.31$ & SRL+Tac & 1.52 & $-1.28-1.80$ \\
\hline HCV- b: Referent* & 1.00 & $1.00-1.00$ & CMV-d: Referent* & 1.00 & $1.00-1.00$ \\
\hline SRL+MPA & 1.41 & - $\quad 1.23-1.61$ & SRL+MPA & 1.46 & $\rightarrow \quad 1.17-1.83$ \\
\hline SRL+Tac & 1.56 & - $1.35-1.81$ & SRL+Tac & 1.76 & $-1.38-2.24$ \\
\hline
\end{tabular}

\begin{tabular}{|c|c|c|c|c|c|c|c|c|c|c|c|c|c|c|c|c|c|}
\hline & ATG & $\begin{array}{l}\text { Alemtu } \\
\text { zumab }\end{array}$ & Age & \begin{tabular}{|l|} 
AA \\
Race
\end{tabular} & \begin{tabular}{|l|} 
Sex \\
Fem.
\end{tabular} & CVD & \begin{tabular}{|l|}
$\mathrm{DMM}$ \\
$1^{\circ} \mathrm{CKD}$
\end{tabular} & \begin{tabular}{|l|l} 
GN \\
$1^{\circ} \mathrm{CKD}$
\end{tabular} & \begin{tabular}{|l|l|} 
HTN \\
$1^{\circ} \mathrm{CKD}$
\end{tabular} & \begin{tabular}{|l|l|} 
Dialysis \\
Pretxp.
\end{tabular} & \begin{tabular}{|l|} 
Tranpl \\
$>2009$
\end{tabular} & $\begin{array}{l}\text { PRA } \\
>20 \%\end{array}$ & $\begin{array}{l}\text { HLA } \\
\mathrm{mm}>3\end{array}$ & Retxp & $\begin{array}{l}\text { Ste- } \\
\text { roid }\end{array}$ & ECD & $S C D$ \\
\hline $\begin{array}{l}\text { Models } 1^{\mathrm{a}} 2^{\mathrm{b}} 3^{\mathrm{C}} 4^{\mathrm{d}} \\
\text { H. R. } \\
\text { P }\end{array}$ & \begin{tabular}{|l}
0.91 \\
.04
\end{tabular} & $\begin{array}{l}1.02 \\
.81\end{array}$ & $\begin{array}{l}1.05 \\
<.001\end{array}$ & $\begin{array}{l}1.00 \\
0.99\end{array}$ & $\begin{array}{l}0.94 \\
.12\end{array}$ & $\begin{array}{l}1.43 \\
<.001\end{array}$ & $\begin{array}{l}2.40 \\
<.001\end{array}$ & $\begin{array}{l}1.286 \\
.006\end{array}$ & $\begin{array}{l}1.65 \\
<.001\end{array}$ & \begin{tabular}{|l}
1.59 \\
$<<001$
\end{tabular} & $\begin{array}{l}0.31 \\
<.001\end{array}$ & $\begin{array}{l}0.98 \\
.66\end{array}$ & $\begin{array}{l}1.02 \\
.55\end{array}$ & $\begin{array}{l}1.40 \\
<.001\end{array}$ & $\begin{array}{l}1.24 \\
<<001\end{array}$ & $\begin{array}{l}1.73 \\
<.001\end{array}$ & $\begin{array}{l}1.33 \\
<.001\end{array}$ \\
\hline
\end{tabular}

Legend: Sirolimus, SRL; Mycophenolate, MPA; Tacrolimus, Tac; *Referent= Tac+MPA; **Each model adjusted for viral serostatus-SRL interactions,the other 3 viral serostatuses and the covariates in the table. 
Figure 65 Year Risk Factors for Death-Censored Graft Loss,

Viral Serostatus-Sirolimus Interaction Cox Models

\begin{tabular}{|c|c|c|}
\hline $\begin{array}{l}\text { Serostatus } x \\
\text { SRL Regimen }\end{array}$ & HR & $95 \% \mathrm{Cl}$ \\
\hline $\mathrm{HBC}+{ }^{\mathrm{a}}$ : Referent* & 1.00 & $1.00-1.00$ \\
\hline SRL+MPA & 2.02 & $\rightarrow 1.40-2.91$ \\
\hline SRL+Tac & 1.16 & - $\quad 0.73-1.85$ \\
\hline HBc- a: Referent* & 1.00 & $1.00-1.00$ \\
\hline SRL+MPA & 1.36 & $1.18-1.55$ \\
\hline SRL+Tac & 1.40 & $1.22-1.61$ \\
\hline HCV+ b: Referent* & 1.00 & $1.00-1.00$ \\
\hline SRL+MPA & 1.56 & $1.02-2.37$ \\
\hline SRL+Tac & 1.17 & $0.68-2.00$ \\
\hline HCV- b: Referent* & 1.00 & $1.00-1.00$ \\
\hline SRL+MPA & 1.40 & $1.23-1.60$ \\
\hline $\mathrm{SRL}+\mathrm{Tac}$ & 1.40 & $1.22-1.60$ \\
\hline
\end{tabular}

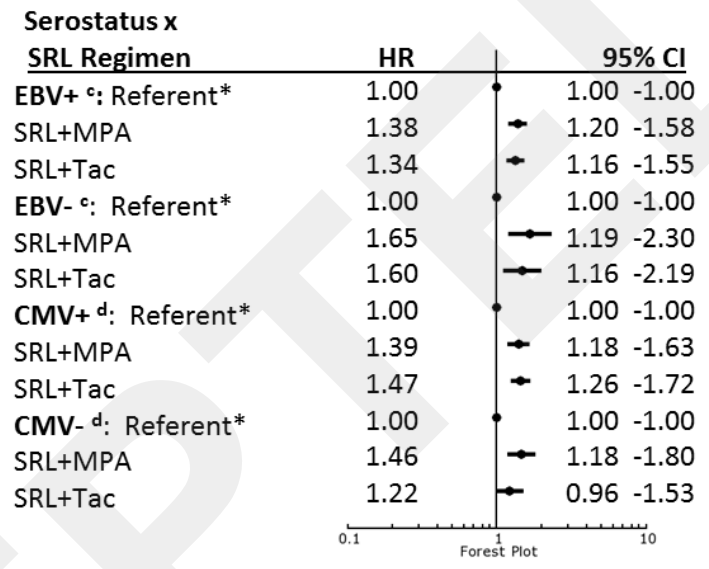

\begin{tabular}{|c|c|c|c|c|c|c|c|c|c|c|c|c|c|c|c|c|c|}
\hline & ATG & $\begin{array}{l}\text { Alemtu } \\
\text { zumab }\end{array}$ & \begin{tabular}{|l|l|} 
Age \\
\end{tabular} & \begin{tabular}{|l|} 
AA \\
Recip. \\
Race
\end{tabular} & \begin{tabular}{|l|} 
Sex \\
Fem.
\end{tabular} & \begin{tabular}{|l|} 
AA \\
Donor \\
Race
\end{tabular} & $\begin{array}{l}\mathrm{DM} \\
1^{\circ} \mathrm{CKD}\end{array}$ & $\begin{array}{l}\mathrm{GN} \\
1^{\circ} \mathrm{CKD}\end{array}$ & \begin{tabular}{|l|l|} 
HTN \\
$1^{\circ} \mathrm{CKD}$
\end{tabular} & \begin{tabular}{|l|} 
Dialysis \\
Pretxp.
\end{tabular} & \begin{tabular}{|l|l|} 
& Tranpl \\
$>2009$
\end{tabular} & $\begin{array}{l}\text { PRA } \\
>20 \%\end{array}$ & $\begin{array}{l}\text { HLA } \\
\mathrm{mm}>3\end{array}$ & Retxp & $\begin{array}{l}\text { Ste- } \\
\text { roid }\end{array}$ & ECD & $S C D$ \\
\hline $\begin{array}{l}\text { Models } 1^{\mathrm{a}} 2^{\mathrm{b}} 3^{\mathrm{C}} 4^{\mathrm{d}} \\
\text { H. R. } \\
\text { P. }\end{array}$ & $\begin{array}{l}0.96 \\
39\end{array}$ & $\begin{array}{l}1.17 \\
03\end{array}$ & $\begin{array}{l}0.97 \\
<001\end{array}$ & $\begin{array}{l}1.62 \\
<001\end{array}$ & $\begin{array}{l}0.97 \\
.45\end{array}$ & \begin{tabular}{|l|l}
1.30 \\
$<001$
\end{tabular} & $\begin{array}{l}1.59 \\
<001\end{array}$ & $\begin{array}{l}1.43 \\
<001\end{array}$ & $\begin{array}{l}1.62 \\
<001\end{array}$ & $\begin{array}{l}1.45 \\
<001\end{array}$ & $\begin{array}{l}0.28 \\
<001\end{array}$ & 1.11 & 1.09 & 1.09 & $\begin{array}{l}1.14 \\
.001\end{array}$ & $\begin{array}{l}2.16 \\
<001\end{array}$ & $\begin{array}{l}1.25 \\
<001\end{array}$ \\
\hline
\end{tabular}

Legend: Sirolimus, SRL; Mycophenolate, MPA; Tacrolimus, Tac; *Referent= Tac+MPA; **Each model adjusted for viral serostatus-SRL interactions, the other 3 viral serostatuses and the covariates in the table. 
Figure 75 Year Risk for Malignancy, Viral Serostatus-Sirolimus Interaction Cox Models

\begin{tabular}{|c|c|c|c|c|c|c|c|c|c|c|c|c|}
\hline Risk Factors & \multicolumn{2}{|l|}{ HR } & \multicolumn{3}{|c|}{$95 \% \mathrm{Cl}$} & \multicolumn{3}{|c|}{ Risk Factors } & HR & & \multicolumn{2}{|c|}{$95 \% \mathrm{Cl}$} \\
\hline \multirow{2}{*}{$\begin{array}{l}\mathrm{HBC}+{ }^{\text {a: }} \text { Referent* } \\
\text { SRL+MPA }\end{array}$} & \multirow{2}{*}{\multicolumn{2}{|c|}{$\begin{array}{l}1.00 \\
0.82\end{array}$}} & \multicolumn{3}{|c|}{$1.00-1.00$} & \multicolumn{3}{|c|}{ EBV+ ${ }^{c}$ : Referent* } & 1.00 & & \multicolumn{2}{|c|}{$1.00-1.00$} \\
\hline & & & \multirow{2}{*}{\multicolumn{3}{|c|}{$\begin{array}{l}0.34-2.01 \\
0.10-1.43\end{array}$}} & \multicolumn{3}{|c|}{ SRL+MPA } & 0.87 & & \multicolumn{2}{|c|}{$0.71-1.08$} \\
\hline SRL+Tac & \multicolumn{2}{|l|}{$\begin{array}{l}0.82 \\
0.36\end{array}$} & & & & \multicolumn{3}{|c|}{$\mathrm{SRL}+\mathrm{Tac}$} & 0.79 & & \multicolumn{2}{|c|}{$0.62-1.02$} \\
\hline HBc- a: Referent* & \multicolumn{2}{|l|}{1.00} & \multicolumn{3}{|c|}{$\begin{array}{l}0.10-1.43 \\
1.00-1.00\end{array}$} & \multicolumn{3}{|c|}{ EBV- c: Referent* } & 1.00 & & \multicolumn{2}{|c|}{$1.00-1.00$} \\
\hline SRL+MPA & \multicolumn{2}{|l|}{0.80} & \multicolumn{3}{|c|}{$0.65-0.98$} & \multicolumn{3}{|c|}{ SRL+MPA } & 0.27 & & \multicolumn{2}{|c|}{$0.10-0.72$} \\
\hline SRL+Tac & \multicolumn{2}{|l|}{0.85} & \multicolumn{3}{|c|}{$0.67-1.07$} & \multirow{2}{*}{\multicolumn{3}{|c|}{$\begin{array}{l}\text { SRL+Tac } \\
\text { CMV+d: Referent* }\end{array}$}} & 0.98 & & \multicolumn{2}{|c|}{$0.52-1.80$} \\
\hline HCV+ b: Referent* & * 1.00 & & \multicolumn{3}{|c|}{$1.00-1.00$} & & & & 1.00 & & & $0-1.00$ \\
\hline SRL+MPA & 1.10 & & & $0.45-2$ & & SRL & +MPA & & 0.93 & & 0.7 & $3-1.19$ \\
\hline $\mathrm{SRL}+\mathrm{Tac}$ & 0.45 & & & $0.11-1$ & & SRL & $+\mathrm{Tac}$ & & 0.89 & & 0.6 & $7-1.18$ \\
\hline HCV- b: Referent* & 1.00 & & & $1.00-1$ & & $\mathrm{CM}$ & I- d: Refe & rent* & 1.00 & & 1.0 & $0-1.00$ \\
\hline SRL+MPA & 0.79 & & & $0.64-c$ & & SRL & MPA & & 0.61 & & 0.4 & $3-0.88$ \\
\hline $\mathrm{SRL}+\mathrm{Tac}$ & 0.83 & & & ب & & SRL & Tac & & 0.69 & & 0.4 & $6-1.04$ \\
\hline & 0.1 & & & & & & & & 0.1 & & & \\
\hline & \begin{tabular}{|l|} 
ATG \\
Induction
\end{tabular} & $\begin{array}{l}\text { ALEM. } \\
\text { Induction }\end{array}$ & Age & AA Race & \begin{tabular}{|l|l|} 
Sex \\
Female \\
\end{tabular} & BMI & \begin{tabular}{|l|} 
DM \\
Prim.CKD \\
\end{tabular} & $\begin{array}{l}\text { GN } \\
\text { Prim. CKD }\end{array}$ & $\begin{array}{l}\text { HTN } \\
\text { Prim. CKD }\end{array}$ & $\begin{array}{l}\text { Dialysis } \\
\text { Pretxp. }\end{array}$ & $\begin{array}{l}\text { Tranplant } \\
\text { Yr. >2009 }\end{array}$ & \begin{tabular}{|l|} 
Steroid \\
Maintenanoe
\end{tabular} \\
\hline $\begin{array}{l}\text { Models } 1^{1} 2^{b} 3^{6} 4^{d} \\
\text { H. R. } \\
\text { P }\end{array}$ & $\begin{array}{l}1.27 \\
<.001\end{array}$ & $\begin{array}{l}1.30 \\
.002\end{array}$ & $\begin{array}{l}1.06 \\
<.001\end{array}$ & $\begin{array}{l}0.60 \\
<.001\end{array}$ & $\begin{array}{l}0.75 \\
<.001\end{array}$ & $\begin{array}{l}1.03 \\
.45\end{array}$ & $\begin{array}{l}0.70 \\
<.001\end{array}$ & $\begin{array}{l}1.05 \\
.49\end{array}$ & $\begin{array}{l}0.80 \\
.001\end{array}$ & $\begin{array}{l}0.77 \\
<.001\end{array}$ & $\begin{array}{l}0.31 \\
<.001\end{array}$ & $\begin{array}{l}1.14 \\
.003\end{array}$ \\
\hline
\end{tabular}

Legend: Sirolimus, SRL; Mycophenolate, MPA; Tacrolimus, Tac; *Referent= Tac+MPA; **Each model adjusted for viral serostatus-SRL interactions, the other 3 viral serostatuses and the covariates in the table. 
Figure 85 Year Outcomes Associated with Sirolimus Regimens at Different Periods in the First Transplant Year

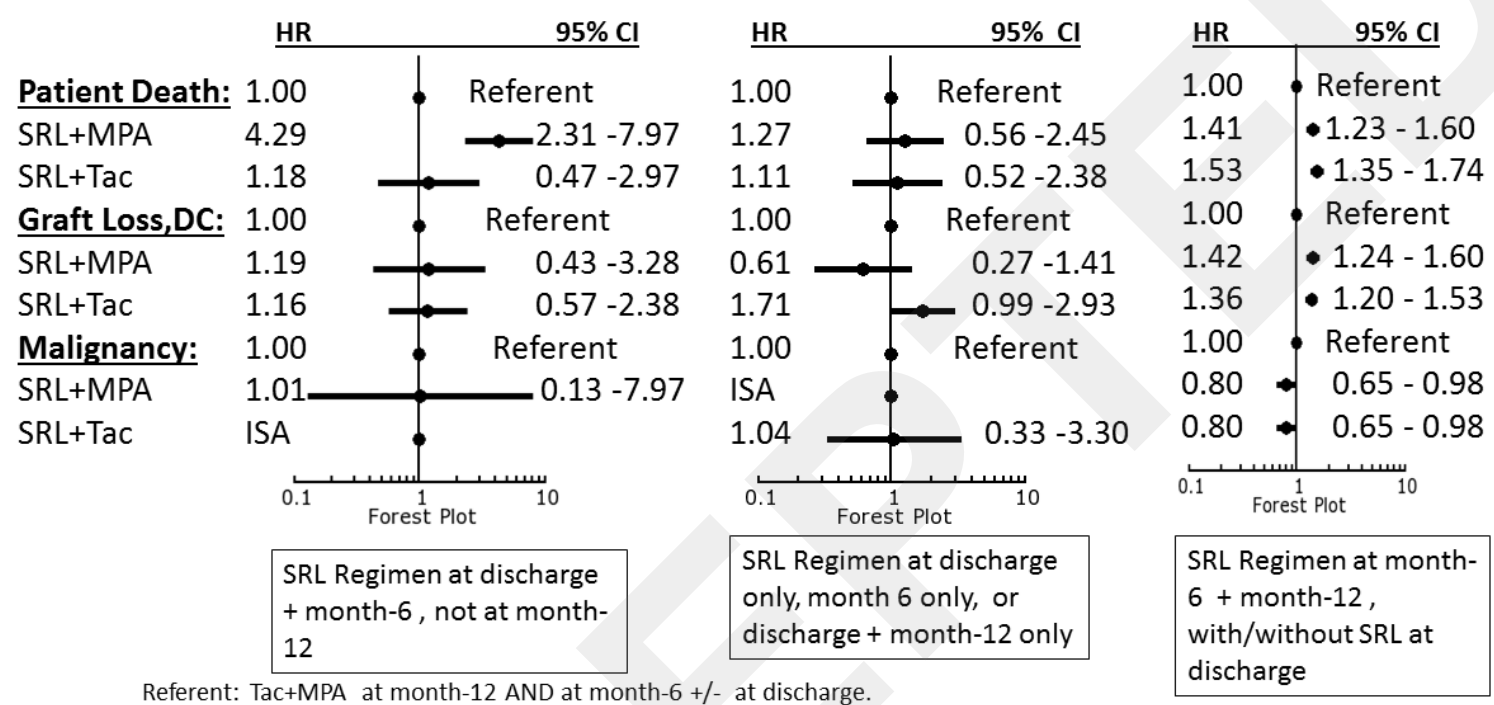

Legend: SRL+MPA, sirolimus and mycophenolate; SRL+Tac, sirolimus and tacrolimus; DC, death-censored; Legend: SRL+MPA, sirolimus and mycor
ISA, insufficient sample for analysis 
TABLE I. Demographic and Clinical Characteristics of US Adult Kidney Transplants Recipients from 2000 through 2013 comprising the 3 immunosuppression cohorts, $N=61$ 590

\begin{tabular}{|c|c|c|c|c|}
\hline Variables & $\begin{array}{c}\text { sirolimus and } \\
\text { mycophenolate } \\
\mathrm{N}=2659\end{array}$ & $\begin{array}{l}\text { sirolimus and } \\
\text { tacrolimus } \\
\mathrm{N}=2167\end{array}$ & $\begin{array}{l}\text { tacrolimus and } \\
\text { mycophenolate }^{\text {a }} \\
\mathrm{N}=56764\end{array}$ & P Value \\
\hline $\begin{array}{l}\text { Pretransplant Viral Serology: } \\
\text { Hepatitis B antibody + } \\
\text { Hepatitis C antibody + } \\
\text { Epstein Barr Virus + } \\
\text { Cytomegalovirus + }\end{array}$ & $\begin{array}{c}180(6.8) \\
122(4.6) \\
2339(88.0) \\
1616(60.8) \\
\end{array}$ & $\begin{array}{c}168(7.8) \\
98(4.5) \\
1881(86.8) \\
1381(63.7) \\
\end{array}$ & $\begin{array}{l}4426(7.8) \\
2517(4.4) \\
49663(87.5) \\
37092(65.3) \\
\end{array}$ & $\begin{array}{l}.02 \\
.92 \\
.48 \\
<.001\end{array}$ \\
\hline $\begin{array}{l}\text { Donor Type: } \\
\text { Expanded Criteria Deceased } \\
\text { Standard Criteria Deceased } \\
\text { Living }\end{array}$ & $\begin{array}{l}363(13.6) \\
1159(43.6) \\
1137(42.8)\end{array}$ & $\begin{array}{c}195(9.0) \\
1054(48.6) \\
918(42.4)\end{array}$ & $\begin{array}{c}4963(8.7) \\
29140(51.3) \\
22661(39.9)\end{array}$ & $<.001$ \\
\hline Donor Age, years: Mean (SD) & $41.8(14.6)$ & $38.1(14.8)$ & $38.7(14.7)$ & $<.001$ \\
\hline Recipient Age, years: Mean (SD) & $48.7(13.4)$ & $46.2(13.6)$ & $49.3(13.7)$ & $<.001$ \\
\hline $\begin{array}{l}\text { Recipient Race: } \\
\text { Black } \\
\text { Other }\end{array}$ & $\begin{array}{c}697(26.2) \\
1962(73.8)\end{array}$ & $\begin{array}{c}599(27.6) \\
1568(75.4)\end{array}$ & $\begin{array}{l}14585(25.7) \\
42179(74.3)\end{array}$ & .11 \\
\hline $\begin{array}{l}\text { Recipient Gender: } \\
\text { Male } \\
\text { Female }\end{array}$ & $\begin{array}{c}1741(65.5) \\
918(34.5)\end{array}$ & $\begin{array}{c}1264(58.3) \\
903(41.7)\end{array}$ & $\begin{array}{l}33881(59.7) \\
22883(40.3)\end{array}$ & $<.001$ \\
\hline $\begin{array}{l}\text { Previous Kidney Transplant: } \\
\text { Yes }\end{array}$ & $\begin{array}{c}242(9.1) \\
2417(90.9)\end{array}$ & $\begin{array}{c}304(14.0) \\
1863(86.0)\end{array}$ & $\begin{array}{c}6483(11.4) \\
50281(88.6)\end{array}$ & $<.001$ \\
\hline Recipient BMI: > = $30 \mathrm{~kg} / \mathrm{m}^{2}$ & $807(31.9)$ & $522(25.6)$ & $17797(32.7)$ & $<.001$ \\
\hline CAD or CAD-equivalent ${ }^{\mathrm{b}}$ & $414(15.6)$ & $245(11.3)$ & $6728(11.8)$ & $<.001$ \\
\hline Pretransplant PRA: PRA $>/=20 \%$ & $565(21.2)$ & $520(24.0)$ & $15269(26.9)$ & $<.001$ \\
\hline HLA mismatch $>3$ & $1501(63.6)$ & $1193(60.9)$ & $33756(65.9)$ & $<.001$ \\
\hline $\begin{array}{l}\text { Primary Kidney Disease: } \\
\text { Diabetes Mellitus } \\
\text { Glomerulonephritis } \\
\text { Hypertension } \\
\text { Polycystic Kidney Disease } \\
\text { Other }\end{array}$ & $\begin{array}{c}614(23.1) \\
609(22.9) \\
714(26.9) \\
259(9.7) \\
463(17.4) \\
\end{array}$ & $\begin{array}{l}424(19.6) \\
560(25.8) \\
525(24.2) \\
225(10.4) \\
433(20.0) \\
\end{array}$ & $\begin{array}{c}13314(23.5) \\
13563(23.9) \\
13647(24.0) \\
5818(10.2) \\
10422(18.4)\end{array}$ & $<.001$ \\
\hline $\begin{array}{l}\text { Pretransplant Dialysis History: } \\
\text { No (Preemptive transplant) } \\
\text { Yes }\end{array}$ & $\begin{array}{c}500(18.8) \\
2159(81.2)\end{array}$ & $\begin{array}{c}374(17.3) \\
1793(82.7)\end{array}$ & $\begin{array}{l}10600(18.7) \\
46164(81.3)\end{array}$ & .25 \\
\hline $\begin{array}{c}\text { Transplant Year: } \\
2000-2009 \\
2010-2013 \\
\end{array}$ & $\begin{array}{c}2230(83.9) \\
429(16.1) \\
\end{array}$ & $\begin{array}{c}2053(94.7) \\
114(5.3) \\
\end{array}$ & $\begin{array}{l}33324(58.7) \\
23440(41.3)\end{array}$ & $<.001$ \\
\hline Steroids in Regimen: & $1818(68.4)$ & $1418(65.4)$ & $38782(68.3)$ & $\begin{array}{l}.02 \\
\end{array}$ \\
\hline $\begin{array}{l}\text { Induction Antibody Agent: } \\
\text { antithymocyte globulin } \\
\text { alemtuzumab } \\
\text { basiliximab } \\
\text { Other }\end{array}$ & $\begin{array}{l}1161(43.7) \\
112(4.2) \\
764(28.7) \\
622(23.4)\end{array}$ & $\begin{array}{c}1300(44.9) \\
35(1.2) \\
855(29.6) \\
702(24.3)\end{array}$ & $\begin{aligned} 25573(45.1) \\
5637(9.9) \\
13358(23.5) \\
12196(21.5)\end{aligned}$ & $<.001$ \\
\hline
\end{tabular}


${ }^{a}$ Based on Scientific Registry of Transplant Recipients Immunosuppression Records Collected at discharge, month-6 and month-12 follow-up, recipients were on same regimen with or without steroids at discharge, $6^{\text {th }}$ month and $12^{\text {th }}$ month or at $6^{\text {th }}$ month and $12^{\text {th }}$ month.

${ }^{\text {b }} \mathrm{CAD}=$ Coronary Artery Disease including angina or coronary artery disease. CAD-equivalent included Diabetes Mellitus, Peripheral Vascular Disease and Cerebro-vascular disea 
TABLE 2. Adjusted Odds Ratio for Continuous Sirolimus Regimen Use for A Minimum of 6 Months Immediately Before and Including the Twelfth Transplant Month in Adult Kidney Allograft Recipients

\begin{tabular}{|c|c|c|c|c|c|c|c|c|c|}
\hline Predictor Variable (Reference) & \multicolumn{3}{|c|}{$\begin{array}{c}\text { SRL + MPA vs. } \\
\text { Tac+ MPA } \\
\text { HR } 95 \% \mathrm{Cl}\end{array}$} & \multicolumn{3}{|c|}{$\begin{array}{c}\text { SRL + Tac vs. } \\
\text { Tac + MPA } \\
\text { HR } 95 \% \text { Cl }\end{array}$} & \multicolumn{3}{|c|}{$\begin{array}{c}\text { SRL +MPA vs. } \\
\text { SRL + Tac } \\
\text { HR } 95 \% \mathrm{Cl}\end{array}$} \\
\hline $\begin{array}{l}\text { atibody }+(-) \\
\text { tibody }+(-) \\
\text { irus }+(-) \\
\text { us }+(-)\end{array}$ & $\begin{array}{l}0.83 \\
1.02 \\
1.12 \\
0.82\end{array}$ & $\begin{array}{l}{[0.70} \\
{[0.83} \\
{[0.98} \\
{[0.75}\end{array}$ & $\begin{array}{l}0.99] \\
1.25] \\
1.28] \\
0.90]\end{array}$ & $\begin{array}{l}0.98 \\
0.84 \\
1.10 \\
0.95\end{array}$ & $\begin{array}{l}{[0.82} \\
{[0.66} \\
{[0.95} \\
{[0.85}\end{array}$ & $\begin{array}{l}1.17] \\
1.07] \\
1.27] \\
1.05]\end{array}$ & $\begin{array}{l}0.87 \\
1.23 \\
1.00 \\
0.88\end{array}$ & $\begin{array}{l}{[0.68} \\
{[0.90} \\
{[0.82} \\
{[0.77}\end{array}$ & $\begin{array}{l}1.12] \\
1.70] \\
1.22] \\
1.02]\end{array}$ \\
\hline $\begin{array}{l}\text { Donor Type: } \\
\text { ECD }^{\mathrm{a}} \text { (Living) } \\
\text { SCD }^{\mathrm{b}} \text { (Living) }\end{array}$ & $\begin{array}{l}1.63 \\
0.90\end{array}$ & $\begin{array}{l}{[1.40} \\
{[0.81}\end{array}$ & $\begin{array}{l}1.89] \\
0.99]\end{array}$ & $\begin{array}{l}1.18 \\
0.99\end{array}$ & & $\begin{array}{l}1.42] \\
1.10]\end{array}$ & $\begin{array}{l}1.35 \\
0.88\end{array}$ & $\begin{array}{l}{[1.07} \\
{[0.76}\end{array}$ & $\begin{array}{l}1.71] \\
1.03]\end{array}$ \\
\hline Recipient Age & 0.99 & {$[0.99$} & $0.998]$ & 0.987 & {$[0.98$} & $0.99]$ & 1.01 & {$[1.00$} & 1.014] \\
\hline ce: Black (Other) & 1.13 & {$[1.02$} & $1.26]$ & 1.12 & {$[1.00$} & 1.25] & 0.98 & {$[0.84$} & 1.14] \\
\hline $\operatorname{Rec}$ & & {$[0$.} & & & & & & 70 & \\
\hline Previo & 0.90 & {$[0.76$} & $1.06]$ & 25 & {$[1.07$} & 1.46] & 0.74 & {$[0.60$} & $0.93]$ \\
\hline Recip & .99 & {$[0.90$} & 1.0 & 83 & {$[0.75$} & $0.93]$ & 1.18 & {$[1.02$} & $1.36]$ \\
\hline$>1 \mathrm{C}$ & & {$[1$.} & 1.4 & 91 & {$[0$.} & 1.0 & 32 & {$[1$.} & \\
\hline PRA: $P$ & .87 & {$[0.78$} & $0.98]$ & .88 & {$[0.78$} & 1.00] & 0.97 & {$[0.82$} & 1.15] \\
\hline HLA m & & {$[0.8$} & 1.0 & & {$[0.79$} & $0.97]$ & 1.08 & {$[0.93$} & $1.24]$ \\
\hline e Diabetes & & & & & & & & & \\
\hline $\begin{array}{l}\text { Mellitus (P } \\
\text { Glomerulc } \\
\text { Hvpertens }\end{array}$ & $\begin{array}{l}1.01 \\
0.96 \\
1.3\end{array}$ & $\begin{array}{l}{[0.85} \\
{[0.81} \\
\Gamma 0.96\end{array}$ & $\begin{array}{l}1.19] \\
1.14]\end{array}$ & $\begin{array}{l}0.90 \\
0.87 \\
0.91\end{array}$ & $\begin{array}{l}{[0.75} \\
{[0.73} \\
\Gamma 0.76\end{array}$ & $\begin{array}{l}1.08] \\
1.04] \\
1.091\end{array}$ & $\begin{array}{l}1.17 \\
1.13 \\
1.26\end{array}$ & $\begin{array}{l}{[0.91} \\
{[0.89} \\
{[0.98}\end{array}$ & $\begin{array}{l}1.50] \\
1.45] \\
1.611\end{array}$ \\
\hline $\begin{array}{l}\text { Hypertension (PCKD) } \\
\text { On dialysis (pre-emptive trans }\end{array}$ & 0.98 & {$[0.86$} & $1.10]$ & 1.10 & {$[0.96$} & $1.26]$ & 0.92 & {$[0.77$} & $1.11]$ \\
\hline Transplant after & & {$[0.26$} & 0.33 & 0.09 & {$[0.07$} & $0.11]$ & 3.21 & {$[2.53$} & 4.08] \\
\hline $\begin{array}{l}\text { Induction Drug: } \\
\text { ATG (basiliximab) } \\
\text { alemtuzumab (basiliximab) }\end{array}$ & $\begin{array}{l}0.92 \\
0.43\end{array}$ & $\begin{array}{l}{[0.83} \\
{[0.35}\end{array}$ & $\begin{array}{l}1.02] \\
0.54]\end{array}$ & $\begin{array}{l}0.90 \\
0.15\end{array}$ & $\begin{array}{l}{[0.80} \\
{[0.10}\end{array}$ & $\begin{array}{l}1.01] \\
0.23]\end{array}$ & $\begin{array}{l}0.96 \\
2.31\end{array}$ & $\begin{array}{l}{[0.82} \\
{[1.41}\end{array}$ & $\begin{array}{l}1.12] \\
3.76]\end{array}$ \\
\hline
\end{tabular}

SRL+MPA, sirolimus and mycopneolate; SRL+Tac, sirolimus and tacrolimus; Tac+MPA, tacrolimus and mycophenolate;

${ }^{a}$ ECD, Expanded Criteria Deceased

${ }^{\mathrm{b}} \mathrm{SCD}$, Standard Criteria Deceased 
${ }^{\mathrm{c}} \mathrm{CAD}=$ Coronary Artery Disease including angina or coronary artery disease. CAD-equivalent included Diabetes Mellitus, Peripheral Vascular Disease and Cerebro-vascular disease 